Accounting and Management Information Systems

Vol. 18, No. 1, pp. 4-24, 2019

DOI: http://dx.doi.org/10.24818/jamis.2019.01001

\title{
Accounting conservatism, financial reporting and stock returns
}

\author{
Belle Selene Xia ${ }^{\mathrm{a}}$, Elia Liitiäinen ${ }^{\mathrm{a}}$ and Ignace De Beelde ${ }^{\mathrm{a}, 1}$ \\ ${ }^{\text {a }}$ Ghent University, Belgium
}

\begin{abstract}
Research Question: One of the aims of this paper is to examine accounting conservatism using a robust set of data collected from the recent years to better understand how accounting conservatism affects the relations between stock returns and accounting variables. Motivation: Financial reporting is increasingly dependent on an in-depth understanding of the imperfections in the capital markets as well as the impact of the accounting standards on firm performance. Idea: The effect of accounting regulations on the firms' reporting practices can be evaluated via a firm's change in cash investments and its operating assets. Data: This study employs a robust set of data with different market to book ratios and corporate governance characteristics collected from Compustat North America Fundamentals Annual firm year observations for the time period of January 1998 to December 2015 fiscal years to better understand how accounting conservatism affects the relations between stock returns and accounting variables. Tools: Compared to the previous studies, any potential improvement in the research method is provided using a regression weight averaged over the years. Findings: There is an improvement in the explanatory power of the estimates of the coefficients on earnings levels and earnings changes when the variables associated with accounting conservatism are incorporated in the analysis. Contribution: Given the ample amount of research done in the international aspects of financial reporting, analyses of differences in results compared to the previous studies and future research opportunities will be provided.
\end{abstract}

Keywords: International and financial accounting; financial reporting; corporate finance; accounting conservatism; capital markets.

${ }^{1}$ Corresponding authors: Department of Accounting and Corporate Finance, Ghent University, Belgium; Sint-Pietersplein 79000 Ghent; tel. (+32) 926435 06; email addresses: belleselene.xia@ugent.be, elia.liitiainen@helsinki.fi; ignace.debeelde@ugent.be 


\section{JEL codes: $M 41$}

\section{Introduction}

The two types of accounting conservatism common in the literature are referred to as conditional and un-conditional conservatism. One of the aims of this paper is to examine accounting conservatism using a robust set of data collected from the recent years to better understand the effect of accounting requirements on financial reporting. The research question of the study is to examine how accounting conservatism affects the relations between stock returns and accounting variables. In this case, a positive coefficient on change in cash investments would capture the first type of accounting conservatism associated with investments in positive present net value projects in a price earnings regression framework; the effects of which will not be reflected in the financial statements until the expected future benefits are realized. A positive coefficient on the change in lagged operating assets would capture the second type of accounting conservatism associated with the application of accounting regulations to operating assets in place. In the first type of accounting conservatism, accounting does not record payoffs from positive net present value projects until the respective future sales are realized. This implies that new cash investments should be added to the pricing model, and thus the change in cash investments should be added to the earnings-return regression estimation. In the second type of accounting conservatism, the impact of accounting regulations may lead to an understatement of book value and accounting earnings in the prior periods, current period and future periods. This implies that the lagged operating assets should be added to the pricing model, and thus the deflated lagged change in operating assets should be added to the earnings-return regression model.

Accounting conservatism whether due to the failure to capture investment in positive net present value (NPV) projects or the accounting rules would result in the understatement of book value (Easton \& Pae, 2004). In the first type of accounting conservatism, cash investments for firms with non-negative returns (good news firms) and for firms with negative returns (bad news firms) should be significantly positive, and thus the estimate of the coefficient on change in cash investments should be positive for both of the sub-samples. In the second type of accounting conservatism, the accounting conservatism is likely to be less prevalent in the valuation of financial assets so that the ratio of the market value of net operating assets to the book value of net operating assets in contrast to the ratio of the market value of common equity to the book value of common equity would be a more accurate measurement of the second type of accounting conservatism. In this case, the higher the ratio of market value of net operating assets to the book value of net operating assets, the more significant the 
coefficients of the regression results. If the current market to book ratio were a good proxy for accounting conservatism, the coefficients on the change in cash investments and the change in lagged operating assets should increase in the results of the estimation model.

In this paper, we will extent the work done by Easton and Harris (1991) by adding two measures of accounting conservatism to the regression analysis of returns on earnings and earnings changes. These two types of accounting conservatism can be captured by the change in cash investments and the lagged operating assets (Easton \& Pae, 2004). These two concepts are extensively employed by numerous papers and several metrics have been developed in the previous literature (Mason, 2004). In this paper, we fully acknowledge the prior studies and the previous literature as the basis of our analysis. In our statistical analysis, a test for the heteroscedasticity of the ordinary least square (OLS) models is performed. Evidence is found showing a significant degree of heteroscedasticity invalidating the classical OLS approach. As a contribution towards a more theoretically correct approach in the research of accounting conservatism and corporate governance, the use of heteroscedasticity robust standard errors are proposed for future research. Moreover, given the ample amount of research done in the international aspects of corporate financial reporting, we will offer potential suggestions of alternative ways that the research question could have been addressed and discuss the implications of the results.

This paper is organized as follows. In the next section, the background and motivation in developing the hypotheses of this paper will be elaborated. The data and method of this study are detailed in the research design and data collection section. The results of the present study will be reported and their implications summarized in the results section. Finally, comparisons results with the previous studies will be discussed and we will conclude our research in the final section of this paper.

\section{Prior research and development of hypotheses}

\subsection{Literature review on accounting conservatism}

One of the important goals of financial statements is to predict unusual circumstances, such as bankruptcies, accounting scandals, takeovers and/or asset revaluations. Ball and Brown (1968) have examined the validity and usefulness of accounting income numbers in terms of their information content and timeliness. They have found that in a well-functioning capital market, changes in stock prices would reflect the information of accounting income. On the other hand, Ball and Shivahumar (2008) suggested that the primary role of reported earnings is not to provide new information to the capital markets in a timely fashion but is more used 
in debt and compensation contracts. This is because accounting earnings is by nature low frequency, not discretionary and primarily backward looking. Consequently, the informativeness of earnings is likely to depend on various firm specific factors, such as the market-to-book ratios, the leverage ratio and the industry type, as it is shown in this paper as well (Wu \& Zhang, 2017).

Accounting conservatism occurs when earnings reflect bad news more quickly than good news and that revenue will be deferred until it is being verified (Pope \& Walker, 2003). This emphasizes the timeliness of loss recognition being one of the primary factors behind contracting efficiency. Accounting conservatism can also be defined as the differential verifiability required for the recognition of profits versus negative returns, which has important implications for the accounting regulations. Therefore, accounting conservatism may result in a persistent understatement of net asset values, which may lead to the overstatement of earnings in the future periods causing an understatement of future expenses respectively. In other words, accounting conservatism addresses the moral hazard caused by the parties to the firm where the conservatism effects would restrict a certain degree of management opportunism (Callen et al., 2016). In the accounting research of corporate governance, the effect of conservatism offers the possibility to investigate the existence of negative net present value projects and direct actions accordingly (Lara et al., 2016).

In this paper, accounting conservatism from two perspectives will be evaluated one where the net present value of future cash flows is not fully reflected and the other where the book value of operating assets may be understated. The former is news based because it depends on the future and the latter is not. These two types of conservatism have been examined in the past literature (such as Easton \& Pae, 2004). Nevertheless, we will provide analyses of differences in the research results compared to the previous studies and offer insights of alternative ways that the research question could have been addressed. In the traditional literature, the research framework for conditional conservatism rests on the assumptions made in the price formation process. If the returns reflect the news irrespective of whether accounting recognizes it or not concurrently, then conditional conservatism can be measured using the difference in slope between the positive and negative regions of returns in a regression with earnings as the dependent variable and returns as the independent variable, as shown by the Basu (1997) estimator. On the other hand, if market learns the news even partially from the accounting disclosures, then a crosssectional comparison of conditional conservatism using the same measure becomes problematic (Callen et al., 2010). Other measures have been proposed to address this issue.

Accounting conservatism can be measured by net asset measures, earnings/accrual measures and earnings/stock returns relation measures (Glover \& Lin, 2018). The research results on the understatement of net assets, the behavior of earnings and 
accruals as well as the earnings/stock return relation are empirically consistent with the existence of accounting conservatism in the US financial reporting practices. On the other hand, Ball and Shivakumar (2005) have used a list of UK firms to evaluate the impact of accounting regulations on auditing, accounting standards and taxes. In terms of reporting quality, they have found differences in results between private and public firms. Moreover, Penman and Zhang (2002) suggested that changes in the amount of a firm's investment affect the quality of earnings when firms practice conservative accounting. This is because growth in investment creates reserves and decline in investment releases those reserves. When investment is temporary, earnings in the current period are temporarily depressed or inflated, and thus cannot reliably predict future earnings. Givoly et al. (2007) have also identified factors unrelated to conservatism that affect the differential timeliness measure, such as the nature of the economic events occurring during the period and the firms' disclosure policies, which implies that the exclusive reliance on any single measure to assess the accounting conservatism of firms is likely to lead to incorrect inferences (Khan \& Watts, 2009). In this paper, the measurement of accounting conservatism is found to be dependent on the year when the data is collected as well as various other firm specific factors.

\subsection{Research objectives and hypotheses development}

Change in cash investments and change in lagged operating assets are added to the regression of returns on earnings and earnings changes to capture the two types of accounting conservatism. In this case, a positive coefficient on change in cash investments would capture the first type of accounting conservatism related to investments in positive net present value projects in the financial statements after the expected future benefits are realized. A positive coefficient on change in lagged operating assets would be observed due to the second type of accounting conservatism associated with the application of accounting rules to operating assets in place. Therefore, the research hypotheses of the present study are formulated as below:

H1. A positive coefficient on change in cash investments captures the first type of accounting conservatism, which is associated with investments in positive net present value projects. The effects are realized in the accounting statements until the expected future benefits have being verified.

H2. A positive coefficient on change in lagged operating assets does not capture the second type of accounting conservatism, which is associated with the application of accounting rules to operating assets in place.

In this paper, we have aimed to extend the regression of returns on earnings and deflated earnings changes model, which expresses price as a linear function of book value and earnings (Easton \& Harris, 1991), to identify the role of 
conservative accounting in firms' financial statements. The variables change in cash investments and change in lagged operation assets are added to the earningsreturn regression estimation in order to capture the economic value added and the accounting value added (Easton \& Pae, 2004). The accounting theory predicts that the averaged estimate of the coefficient on earnings levels in the regression of returns on deflated earnings should be significantly positive, and that the estimate of the averaged coefficient on the change in lagged operating assets should be significantly different from zero. In terms of the variable change in cash investments, some empirical evidence is found to accounting conservatism reflecting the effects of investments in positive net present value projects until later periods when accounting conservatism is measured using the change in cash investments. In terms of the variable lagged operating assets, the estimates of the coefficient on operating assets are not found to be statistically significant to empirically justify the second type of accounting conservatism using the lagged operating assets.

\section{Methods and data collection}

\subsection{Data collection}

The data used for our empirical analysis includes the CRSP US stock database and the Compustat North America Fundamental annual firm-year observations collected for the time period of January 1998 to December 2015 fiscal years for the following variables of analysis (the acronyms refer to those used by CRSP; the mathematical symbols used to refer to these variables are detailed below):

- Return $\left(\right.$ ret $\left._{t}\right)$ is obtained from CRSP Stock / Monthly Security Files by compounding the monthly returns.

- Comprehensive income $\left(x_{t}\right)$ is expressed as net income (NI - net income/loss) minus preferred dividends (DVP - dividend, preferred/preference) plus the change in value of marketable securities (MSA Marketable Securities Adjustment) plus the change in the cumulative foreign currency translation adjustment (RECTA - retained earnings cumulative translation adjustment). $\Delta \mathrm{x}_{\mathrm{t}}$ denotes the change in comprehensive income. Our approach extends that in Easton and Pae (2004), where the use of comprehensive income stems from the pricing equation. In this case, comprehensive income is chosen instead of net income/EBIT based on the expected relation between the measurement of operating assets and the type of income. As comprehensive income is consisted of all of the revenues, gains, expenses, and losses that caused the stockholders' equity to change during the accounting period, it is found to fairly well represent the firm's financial reporting.

- Dividends $\left(d_{t}\right)$ are expressed as the sum of dividends to common shareholders (DVC - dividends common/ordinary) and net capital contributions. Net capital 
contributions are expressed as the purchases of common and preferred stock (PRSTKC - Purchase of Common and Preferred Stock) minus the sales of common and preferred stock (SSTK - Sale of Common and Preferred Stock).

- Operating assets $\left(o a_{t}\right)$ are expressed as the book value of equity $\left(b_{t}\right)$ minus financial assets $\left(\mathrm{fa}_{\mathrm{t}}\right)$. The market value of operating assets is calculated as the market value of equity minus financial assets $\left(\mathrm{p}_{\mathrm{t}}-\mathrm{fa}_{\mathrm{t}}\right)$. $\Delta \mathrm{oa}_{\mathrm{t}}$ denotes the change in operating assets.

- - Book value of equity $\left(b_{t}\right)$ is expressed as common equity (CEQ - Common Equity - Total (Utility)) plus preferred treasury stock (TSTKP - Treasury Stock - Preferred) minus preferred dividends in arrears (DVPA - Preferred Dividends in Arrears).

- Financial assets $\left(f a_{t}\right)$ are expressed as cash and short-term investments (CHE Cash and Short-Term Investments) plus investments and advances-others (IVAO - Investments and Advances - Other) minus debt in current liabilities (DLC - Debt in Current Liabilities) minus long-term debt (DLTT -Long-Term Debt - Total) minus preferred stock (PSTK - Preferred/Preference Stock) plus preferred treasury stock (TSTKP - Treasury Stock - Preferred) minus preferred dividends in arrears (DVPA - Preferred Dividends in Arrears) minus minority interest (MIB - Minority Interest [Balance Sheet]).

- Cash investments $\left(c_{t}\right)$ are calculated from the cash flow statement as capital expenditures (CAPX - Capital Expenditures) minus the sale of property, plant and equipment (SPPE - Sales of Property) plus acquisitions (AQC Acquisitions) minus other investing activities (IVACO - Investing Activities Other). $\Delta \mathrm{c}_{\mathrm{t}}$ denotes the change in cash investments.

- The Market value of equity $\left(p_{t}\right)$ is obtained by Common Shares Outstanding (CSHO - Common Shares Outstanding) multiplied by price (PRCC_F - Price Close - Annual - Fiscal).

- The ratio of the market value of operating assets to the book value of operating assets $\left(o a b_{t}\right)$ is expressed as the market value of common equity minus financial assets divided by the book value of operating assets.

The depreciation rate is expressed as depreciation and amortization expenses (DP - Depreciation and Amortization) divided by the sum of beginning property, plant and equipment (Property, Plant and Equipment Net - Total (PPENT)), intangibles assets (INTAN Intangible Assets - Total) and advertising expenses (XAD).

The data set is consisted of both active and non-active firms during the specified period. The Compustat and CRSP data is merged using the CUSIP codes. The currency is measured in USD or CAD. Observations with missing or negative book value of equity, market value of operating assets or book value of operating assets are deleted from the sample. The utilities (SIC 4900-4999) and the financial industry (SIC 6000-6411) are excluded. 
For modeling purposes, all of the variables except the market value of equity, annual stock returns, and the ratio of the market value of operating assets to the book value of operating assets are deflated by the beginning market value of equity. After computing the lagged and deflated values, the data is restricted to the time interval of 2000-2015 resulting in total 44758 observations.

In order to address the presence of possible outliers and extreme value, the data is truncated at the $1 \%$ and $99 \%$ fractiles for the following variables: annual returns and deflated comprehensive income, change in comprehensive income, lagged dividends, change in cash investment and change in lagged operating assets. The final sample is consisted of 23340 firm-year observations, 13044 observations with non-negative returns and 10296 observations with negative returns, which represent the good news firms and the bad news firms, respectively.

It is acknowledged that the period under investigation is relatively long, and thus that the underlying accounting rules may have changed during the period of analysis. In order to control for the effect of changes in the accounting standards on the comparability of the accounting figures over time, we have also aimed to control for the year's effect. One key advantage of using a relatively long period of analysis is the allowance for repeated observations of the same variables over time to discover possible trends and patterns in the data across time.

\subsection{Accounting conservatism estimation model}

A model on the value relevance of accounting expresses price as a linear function of book value and earnings:

$$
p_{t, j}=\beta_{0}+\beta_{1} b_{t, j}+\beta_{2} x_{t, j}+e_{t, j}
$$

In order to take into account the two types of accounting conservatism discussed before, namely the accounting conservatism related to investments in positive net present value projects and the accounting conservatism due to the accounting regulations, the lagged book value of operating assets and cash investments are added to the pricing model:

$$
p_{t, j}=\beta_{0}+\beta_{1} b_{t, j}+\beta_{2} x_{t, j}+\beta_{3} c_{t, j}+\beta_{4} o a_{t-1, j}+e_{t, j} .
$$

The Feltham and Ohlson (1996) model is consistent with the intuition behind the pricing model expressed in Equation (2). The Feltham and Ohlson (1996) model includes information on the cash flow dynamics, the present value of cash flow relation and the operating assets relation in which the assumption that the net financial assets are valued at market can be used to derive the valuation relation 
(Feltham \& Ohlson, 1995). For our analysis, we will use the following empirical analogue of Equation (2) derived in Easton and Pae (2004):

$$
\operatorname{ret}_{t, j}=\beta_{0}+\beta_{1} \frac{x_{t, j}}{p_{t-1, j}}+\beta_{2} \frac{\Delta x_{t, j}}{p_{t-1, j}}+\beta_{3} \frac{d_{t-1, j}}{p_{t-1, j}}+\beta_{4} \frac{\Delta c_{t, j}}{p_{t-1, j}}+\beta_{5} \frac{\Delta o a_{t-1, j}}{p_{t-1, j}}+\varepsilon_{t, j}
$$

where $\Delta$ represents the first differences and the return relates to price and dividends by

$$
\operatorname{ret}_{t, j}=\frac{p_{t, j}+d_{t, j}-p_{t-1, j}}{p_{t-1, j}}
$$

The subscript $j$ denotes an observation for a given firm. In this case, the first type of accounting conservatism related to future positive NPV projects is captured by the coefficient $\beta_{4}$ and the second type of accounting conservatism due to the accounting regulations is captured by the coefficient $\beta_{5}$. That is, the effect of economic value added can be captured by the coefficient on change in cash investments, and the effect of accounting value added can be captured by the coefficient on change in lagged operating assets.

It should be noted that the error term $\varepsilon_{t, j}$ is not guaranteed to be homoscedastic. For this reason, we have tested for heteroscedasticity and provided heteroscedasticity consistent estimates. Without such a methodology, the consistency of the statistical estimation is not guaranteed even in the asymptotic limit of an infinite number of observations, as there does not seem to exist theoretical reasons for assuming homoscedasticity a priori.

While Equation (3) does not contain an explicit term for the year of the observation, our empirical models are computed for each year separately. In our analysis, we will also examine the good news (positive earnings) and bad news firms as separate groups in order to capture the different characteristics of the two groups as explained in Easton and Pae (2004).

\section{Empirical results}

\subsection{Descriptive statistics}

Table 1 and 2 show the descriptive statistics of the data sample with separate statistics for the good news and the bad news firms based on the firm observations for the years 2000-2015. From Table 1, the mean market value of 
equity is $\$ 3026.35$ million, which is more than the respective figure presented for the bad news firms ( $\$ 2230.81$ million) but less than the figure presented for the good news firms ( $\$ 3654.30$ million). Over the 16 years, the average annual return is $13 \%$. As expected, the good news firms have performed better than average having an average annual return of $47 \%$, while the annual return for the bad news firms is $-30 \%$. When it comes to comprehensive income, the mean figures are similar across the different firms with a respectively low mean percentage of change.

A similar pattern is observed when it comes to lagged dividend. When the mean value of the lagged dividend for the firms stay the same, this implies a consistent dividend policy. The decomposition of book value of equity into operating assets and financial assets shows that firms have on average net financial obligations. Therefore, it is seen that the mean operating assets is higher than the book value of equity. The positive change in operating assets implies that on average there is an increase in operating assets. Moreover, the mean ratio of the market value of operating assets to the book value of operating assets is on average greater than 1 for both the good news and the bad news firms. The data sample contains more good news firms than bad news firms. The good news firms also seem to have a higher market to book ratio than the bad news firms.

Table 1. Descriptive statistics of the key variables

\begin{tabular}{|c|c|c|c|c|c|}
\hline & Min & Max & Std & Mean & Median \\
\hline $\mathrm{p}_{\mathrm{t}}$ & 0.42 & 467092.88 & 13820.39 & 3026.35 & 367.17 \\
\hline ret $_{t}$ & -0.87 & 3.09 & 0.55 & 0.13 & 0.06 \\
\hline$x_{t}$ & -1.18 & 0.44 & 0.15 & 0.00 & 0.04 \\
\hline$\Delta \mathrm{x}_{\mathrm{t}}$ & -0.77 & 1.40 & 0.16 & 0.01 & 0.00 \\
\hline$d_{t-1}$ & -0.36 & 12.84 & 0.11 & 0.01 & 0.00 \\
\hline$\Delta c_{t}$ & -0.89 & 11.53 & 0.20 & 0.01 & 0.00 \\
\hline$b_{t}$ & 0.00 & 13.07 & 0.57 & 0.67 & 0.54 \\
\hline $\mathrm{fa}_{\mathrm{t}}$ & -32.94 & 4.44 & 0.81 & -0.13 & 0.03 \\
\hline$o a_{t}$ & 0.00 & 42.29 & 1.09 & 0.80 & 0.49 \\
\hline$\Delta \mathrm{oa}_{\mathrm{t}-1}$ & -1.81 & 1.18 & 0.23 & 0.02 & 0.01 \\
\hline$\Delta \mathrm{oa}_{\mathrm{t}}$ & -6.42 & 16.20 & 0.32 & 0.04 & 0.01 \\
\hline$o a b_{t}$ & 0.00 & 72226.91 & 696.80 & 17.42 & 1.98 \\
\hline
\end{tabular}

Note: As defined in Section 3.1, the variables include the market value of equity $\left(\mathrm{p}_{\mathrm{t}}\right)$, return $\left(\mathrm{ret}_{\mathrm{t}}\right)$, comprehensive income $\left(\mathrm{x}_{\mathrm{t}}\right)$, lagged dividends $\left(\mathrm{d}_{\mathrm{t}-1}\right)$, change in cash investments $\left(\Delta c_{t}\right)$, book value of equity $\left(b_{t}\right)$, financial assets $\left(f_{t}\right)$, operating assets $\left(\mathrm{oa}_{t}\right)$ and ratio of the market value of operating assets to the book value of operating assets $\left(o_{a b}\right)_{t}$. All variables in the table except $p_{t}$, ret $t_{t}$ and $o_{a b} b_{t}$ have been deflated by $p_{t-1}$. The differences are computed prior to deflating; specifically, $\Delta \mathrm{x}_{\mathrm{t}}=\left(\mathrm{x}_{\mathrm{t}}-\mathrm{x}_{\mathrm{t}-1}\right) / \mathrm{p}_{\mathrm{t}-1}, \Delta \mathrm{c}_{\mathrm{t}}=\left(\mathrm{c}_{\mathrm{t}}-\mathrm{c}_{\mathrm{t}-1}\right) / \mathrm{p}_{\mathrm{t}-1}$, $\Delta \mathrm{oa}_{\mathrm{t}-1}=\left(\mathrm{oa}_{\mathrm{t}-1}-\mathrm{Oa}_{\mathrm{t}-2}\right) / \mathrm{p}_{\mathrm{t}-1}$ and $\Delta \mathrm{oa}_{\mathrm{t}}\left(\mathrm{oa}_{\mathrm{t}}-\mathrm{Oa}_{\mathrm{t}-1}\right) / \mathrm{p}_{\mathrm{t}-1}$. The total number of observations is 23340. 
Table 2. Descriptive statistics of good and bad news firms with means and medians for both groups

\begin{tabular}{|c|c|c|c|c|c|c|c|c|c|}
\hline & \multicolumn{4}{|c|}{ Good News Firms $(\mathrm{N}=13044)$} & \multicolumn{5}{|c|}{ Bad News Firms $(\mathrm{N}=10296)$} \\
\hline & Min & Max & Std & Mean/Md. & Min & Max & Std & Mean/Md. & $\mathrm{p}$ \\
\hline $\mathrm{p}_{\mathrm{t}}$ & 2.09 & 382421.05 & 14917.31 & $\begin{array}{l}3654.30 / \\
542.96\end{array}$ & 0.42 & 467092.88 & 12245.48 & $\begin{array}{l}2230.81 / \\
228.79\end{array}$ & $0.00 / 0.00$ \\
\hline ret $_{t}$ & 0.00 & 3.09 & 0.49 & $0.47 / 0.31$ & -0.87 & 0.00 & 0.22 & $\begin{array}{l}-0.30 / \\
-0.25\end{array}$ & $0.00 / 0.00$ \\
\hline $\mathrm{X}_{\mathrm{t}}$ & -1.14 & 0.44 & 0.14 & $0.03 / 0.05$ & -1.18 & 0.40 & 0.16 & $-0.03 / 0.02$ & $0.00 / 0.00$ \\
\hline$\Delta \mathrm{x}_{\mathrm{t}}$ & -0.76 & 1.40 & 0.16 & $0.03 / 0.01$ & -0.77 & 1.36 & 0.16 & $\begin{array}{l}-0.03 / \\
-0.01\end{array}$ & $0.00 / 0.00$ \\
\hline$d_{t-1}$ & -0.36 & 12.84 & 0.14 & $0.01 / 0.00$ & -0.36 & 2.26 & 0.08 & $0.00 / 0.00$ & $0.00 / 0.00$ \\
\hline$\Delta \mathrm{c}_{\mathrm{t}}$ & -0.89 & 5.26 & 0.20 & $0.02 / 0.00$ & -0.87 & 11.53 & 0.20 & $0.00 / 0.00$ & $0.00 / 0.00$ \\
\hline $\mathrm{b}_{\mathrm{t}}$ & 0.00 & 13.07 & 0.62 & $0.74 / 0.60$ & 0.00 & 9.35 & 0.49 & $0.58 / 0.47$ & $0.00 / 0.00$ \\
\hline $\mathrm{fa}_{\mathrm{t}}$ & -13.63 & 4.44 & 0.79 & $-0.10 / 0.04$ & -32.94 & 1.96 & 0.84 & $-0.16 / 0.02$ & $0.00 / 0.00$ \\
\hline oat & 0.00 & 18.22 & 1.10 & $0.85 / 0.53$ & 0.00 & 42.29 & 1.09 & $0.74 / 0.44$ & $0.00 / 0.00$ \\
\hline $\begin{array}{l}\Delta \mathrm{oa}_{\mathrm{t}-} \\
1\end{array}$ & -1.81 & 1.16 & 0.23 & $0.01 / 0.01$ & -1.81 & 1.18 & 0.22 & $0.03 / 0.02$ & $0.00 / 0.00$ \\
\hline$\Delta \mathrm{oa}_{\mathrm{t}}$ & -6.42 & 8.25 & 0.30 & $0.05 / 0.02$ & -1.95 & 16.20 & 0.34 & $0.02 / 0.01$ & $0.00 / 0.00$ \\
\hline$o a b_{t}$ & 0.01 & 72226.91 & 709.40 & $\begin{array}{l}19.53 / \\
2.41\end{array}$ & 0.00 & 67768.21 & 680.53 & $\begin{array}{l}14.75 / \\
1.55\end{array}$ & $0.60 / 0.00$ \\
\hline
\end{tabular}

Note: The rightmost column displays the p-values produced by the t-test for the difference of mean, assuming independent samples and non-equal variance, together with those from the chi-square test for the difference of medians (rightmost value). $\mathrm{N}$ denotes the number of samples in each category.

Table 3 shows the Pearson and Spearman correlations of the following variables: market value of equity, annual stock return, comprehensive income, the change in comprehensive income, the lagged cash dividends to common shareholders and net capital distributions, the change in cash investments, the lagged change in operating assets as well as the ratio of the market value of operating assets to the book value of operating assets. In Table 3, the related p-values are observed, where we are interested in the correlations of variables with a significance level less than 0.05 and 0.01 . Most of the correlations are found to be statistically significant. The correlations between the annual returns and the independent variables of market equity, comprehensive income, lagged dividend and the change in cash investment are found to be significant at the 0.05 level. In the data sample, a negative correlation between the change in lagged operating assets and the change in comprehensive income is seen. This implies that the financial 
performance and the profit level of a firm are dependent on its dividend and cash policies and that these variables would affect each other resulting also in a vice versa effect.

Table 3. Pearson and Spearman correlation analysis

\begin{tabular}{|c|c|c|c|c|c|c|c|c|}
\hline & $\mathrm{p}_{\mathrm{t}}$ & ret $_{t}$ & $\mathrm{X}_{\mathrm{t}}$ & $\Delta \mathrm{x}_{\mathrm{t}}$ & $\mathrm{d}_{\mathrm{t}-1}$ & $\Delta c_{t}$ & $\Delta \mathrm{oa}_{\mathrm{t}-1}$ & $\mathrm{oab}_{\mathrm{t}}$ \\
\hline $\mathrm{p}_{\mathrm{t}}$ & & $\begin{array}{l}0.01 \\
(0.03)\end{array}$ & $\begin{array}{l}0.07 \\
(<0.01)\end{array}$ & $0(0.95)$ & $\begin{array}{l}0.04 \\
(<0.01)\end{array}$ & $0(0.50)$ & $\begin{array}{l}0.02 \\
(<0.01)\end{array}$ & $\begin{array}{l}0.01 \\
(0.31)\end{array}$ \\
\hline $\operatorname{ret}_{\mathrm{t}}$ & $\begin{array}{l}0.20 \\
(<0.01)\end{array}$ & & $\begin{array}{l}0.21 \\
(<0.01)\end{array}$ & $\begin{array}{l}0.26 \\
(<0.01)\end{array}$ & $\begin{array}{l}0.04 \\
(<0.01)\end{array}$ & $\begin{array}{l}0.05 \\
(<0.01)\end{array}$ & $\begin{array}{l}-0.08 \\
(<0.01)\end{array}$ & $\begin{array}{l}0.01 \\
(0.09)\end{array}$ \\
\hline $\mathrm{x}_{\mathrm{t}}$ & $\begin{array}{l}0.24 \\
(<0.01)\end{array}$ & $\begin{array}{l}0.35 \\
(<0.01)\end{array}$ & & $\begin{array}{l}0.33 \\
(<0.01)\end{array}$ & $\begin{array}{l}0.10 \\
(<0.01)\end{array}$ & $\begin{array}{l}0.04 \\
(<0.01)\end{array}$ & $\begin{array}{l}0.16 \\
(<0.01)\end{array}$ & $0(0.60)$ \\
\hline$\Delta \mathrm{x}_{\mathrm{t}}$ & $\begin{array}{l}0.06 \\
(<0.01)\end{array}$ & $\begin{array}{l}0.33 \\
(<0.01)\end{array}$ & $\begin{array}{l}0.44 \\
(<0.01)\end{array}$ & & $\begin{array}{l}-0.01 \\
(0.03)\end{array}$ & $\begin{array}{l}-0.03 \\
(<0.01)\end{array}$ & $\begin{array}{l}-0.36 \\
(<0.01)\end{array}$ & $0 \quad(0.86)$ \\
\hline$d_{t-1}$ & $\begin{array}{l}0.19 \\
(<0.01)\end{array}$ & $\begin{array}{l}0.10 \\
(<0.01)\end{array}$ & $\begin{array}{l}0.24 \\
(<0.01)\end{array}$ & $\begin{array}{l}-0.05 \\
(<0.01)\end{array}$ & & $\begin{array}{l}-0.01 \\
(0.14)\end{array}$ & $\begin{array}{l}-0.08 \\
(<0.01)\end{array}$ & $0(0.70)$ \\
\hline$\Delta c_{t}$ & $\begin{array}{l}0.06 \\
(<0.01)\end{array}$ & $\begin{array}{l}0.06 \\
(<0.01)\end{array}$ & $\begin{array}{l}0.09 \\
(<0.01)\end{array}$ & $\begin{array}{l}0.01 \\
(0.17)\end{array}$ & $\begin{array}{l}-0.02 \\
(<0.01)\end{array}$ & & $\begin{array}{l}-0.19 \\
(<0.01)\end{array}$ & $0(0.95)$ \\
\hline$\Delta \mathrm{oa}_{\mathrm{t}-1}$ & $\begin{array}{l}0.09 \\
(<0.01)\end{array}$ & $\begin{array}{l}-0.06 \\
(<0.01)\end{array}$ & $\begin{array}{l}0.11 \\
(<0.01)\end{array}$ & $\begin{array}{l}-0.18 \\
(<0.01)\end{array}$ & $\begin{array}{l}-0.07 \\
(<0.01)\end{array}$ & $\begin{array}{l}-0.21 \\
(<0.01)\end{array}$ & & $0(0.66)$ \\
\hline $\mathrm{oab}_{\mathrm{t}}$ & $\begin{array}{l}0.37 \\
(<0.01)\end{array}$ & $\begin{array}{l}0.28 \\
(<0.01)\end{array}$ & $\begin{array}{l}0.03 \\
(<0.01)\end{array}$ & $\begin{array}{l}0.12 \\
(<0.01)\end{array}$ & $\begin{array}{l}-0.08 \\
(<0.01)\end{array}$ & $\begin{array}{l}0.06 \\
(<0.01)\end{array}$ & $\begin{array}{l}-0.08 \\
(<0.01)\end{array}$ & \\
\hline
\end{tabular}

Note: Spearman correlation coefficients are displayed below the diagonal, whereas the upper diagonal shows the Pearson correlations. As defined in Section 3.1, the variables include market value of equity $\left(\mathrm{p}_{\mathrm{t}}\right)$, return $\left(\mathrm{ret}_{\mathrm{t}}\right)$, comprehensive income $\left(\mathrm{x}_{\mathrm{t}}\right)$, lagged dividends $\left(\mathrm{d}_{\mathrm{t}-1}\right)$, change in cash investments $\left(\Delta \mathrm{c}_{\mathrm{t}}\right)$, lagged change in operating assets $\left(\Delta \mathrm{oa}_{\mathrm{t}-1}\right)$ and the ratio of the market value of operating assets to the book value of operating assets $\left(\mathrm{oab}_{\mathrm{t}}\right)$. The figures inside the parentheses describe the related p-values. The correlation analysis was performed with deflated variables (divided by $\left.\mathrm{p}_{\mathrm{t}-1}\right)$, except for the total market equity $\left(\mathrm{p}_{\mathrm{t}}\right)$, return $\left(\right.$ ret $\left._{\mathrm{t}}\right)$ and the ratio of operating assets to book value $\left(\mathrm{oab}_{\mathrm{t}}\right)$.

\subsection{Multivariate results}

Prior to performing an OLS regression analysis of our data, it is important to perform a power test for heteroscedasticity to ensure consistent results. Table 4 reports the results for the White's test for heteroscedasticity computed for each year individually in order to verify whether the variance of errors in our models is constant, namely homoscedastic. Any observations with missing values are removed prior to the statistical test and the regression analysis. In cases where the result of the White test is statistically significant, the presence of heteroscedastic residuals for the given year is indicated. As all the p-values in Table 4 are relatively small, a heteroscedasticity robust analysis is required. In order to achieve this objective, we have computed the standard heteroscedasticity robust weight covariance matrix as outlined in White (1980) and the related Wald test for the model under analysis to verify the value of the parameter based on the estimate of the data sample. 
Table 4. White's test for heteroscedasticity

year $\quad \begin{array}{llllllllllllllll}2000 & 2001 & 2002 & 2003 & 2004 & 2005 & 2006 & 2007 & 2008 & 2009 & 2010 & 2011 & 2012 & 2013 & 2014 & 2015\end{array}$ p-value $<0.01<0.01<0.01<0.01<0.01<0.01 \quad 0.03<0.01<0.01<0.01<0.01<0.01<0.01<0.01<0.01 \quad 0.01$

\subsubsection{Test of hypothesis 1}

Table 5 reports the results from the regression of equation (3) for the year period of 2000-2015. In addition to the regression coefficients, a heteroscedasticity robust test statistic has been computed. In case of missing values, we have chosen to use the list wise deletion method to process them. Based on the data sample, the theoretical predictions of positive coefficients on earnings levels, earnings changes and lagged dividends may be justified. While there exist negative coefficients for the lagged dividends, they are rejected at the 0.05 confidence level excluding the years 2003 and 2007. The coefficient estimates on the change in cash income remain positive for those years in which the results are statistically significant at the 0.05 level. This supports the fact that accounting conservatism would reflect the effects of investments in positive net present value projects until later periods when accounting conservatism is measured using the change in cash investments but that the results are dependent on the year when the data is collected and other firm specific factors.

Table 5. Year-by-year regressions of returns

\begin{tabular}{|c|c|c|c|c|c|c|c|c|}
\hline Year & Intercept & $\mathrm{x}_{\mathrm{t}}$ & $\Delta \mathrm{x}_{\mathrm{t}}$ & $d_{t-1}$ & $\Delta c_{t}$ & $\Delta \mathrm{oa}_{\mathrm{t}-1}$ & Adj. $R^{2}$ & Model $\mathrm{p}$ \\
\hline 2000 & $\begin{array}{l}-0.03 \\
(1.91)\end{array}$ & $\begin{array}{l}0.95 \\
(7.33) *\end{array}$ & $\begin{array}{l}0.34 \\
(3.05) *\end{array}$ & $\begin{array}{l}0.24 \\
(1.79)\end{array}$ & $\begin{array}{l}0.20 \\
(4.12) *\end{array}$ & $\begin{array}{l}-0.08 \\
(1.37)\end{array}$ & 0.11 & 0.00 \\
\hline 2001 & $\begin{array}{l}0.25 \\
(>10) *\end{array}$ & $\begin{array}{l}0.79 \\
(6.86) *\end{array}$ & $\begin{array}{l}0.64 \\
(5.13) *\end{array}$ & $\begin{array}{l}0.04 \\
(0.67)\end{array}$ & $\begin{array}{l}0.10 \\
(1.26)\end{array}$ & $\begin{array}{l}-0.10 \\
(1.35)\end{array}$ & 0.15 & 0.00 \\
\hline 2002 & $\begin{array}{l}-0.09 \\
(8.21)\end{array}$ & $\begin{array}{l}0.75 \\
(7.73) *\end{array}$ & $\begin{array}{l}0.29 \\
(2.89) \text { * }\end{array}$ & $\begin{array}{l}0.61 \\
(4.01) *\end{array}$ & $\begin{array}{l}0.19 \\
(2.92) *\end{array}$ & $\begin{array}{l}-0.12 \\
(2.12) *\end{array}$ & 0.15 & 0.00 \\
\hline 2003 & $\begin{array}{l}0.57 \\
(>10)\end{array}$ & $\begin{array}{l}0.03 \\
(0.3)\end{array}$ & $\begin{array}{l}0.84 \\
(7.3) *\end{array}$ & $\begin{array}{l}-0.70 \\
(2.87) *\end{array}$ & $\begin{array}{l}0.09 \\
(0.81)\end{array}$ & $\begin{array}{l}-0.02 \\
(0.29)\end{array}$ & 0.08 & 0.00 \\
\hline 2004 & $\begin{array}{l}0.16 \\
(>10) *\end{array}$ & $\begin{array}{l}0.82 \\
(5.33) *\end{array}$ & $\begin{array}{l}0.77 \\
(5.52) *\end{array}$ & $\begin{array}{l}0.21 \\
(1.01)\end{array}$ & $\begin{array}{l}0.28 \\
(3.1) *\end{array}$ & $\begin{array}{l}0.02 \\
(0.16)\end{array}$ & 0.13 & 0.00 \\
\hline 2005 & $\begin{array}{l}0.05 \\
(4.3) *\end{array}$ & $\begin{array}{l}1.12 \\
(8.71) *\end{array}$ & $\begin{array}{l}0.43 \\
(2.83) *\end{array}$ & $\begin{array}{l}0.09 \\
(0.55)\end{array}$ & $\begin{array}{l}0.16 \\
(1.83)\end{array}$ & $\begin{array}{l}-0.05 \\
(0.49)\end{array}$ & 0.12 & 0.00 \\
\hline 2006 & $\begin{array}{l}0.16 \\
(>10)\end{array}$ & $\begin{array}{l}0.58 \\
(4.41) *\end{array}$ & $\begin{array}{l}0.63 \\
(4.88) *\end{array}$ & $\begin{array}{l}-0.05 \\
(0.4)\end{array}$ & $\begin{array}{l}0.16 \\
(3.14) *\end{array}$ & $\begin{array}{l}0.06 \\
(0.67)\end{array}$ & 0.08 & 0.00 \\
\hline 2007 & $\begin{array}{l}0.00 \\
(0.08)\end{array}$ & $\begin{array}{l}1.00 \\
(6.85) *\end{array}$ & $\begin{array}{l}0.59 \\
(3.25) *\end{array}$ & $\begin{array}{l}-0.41 \\
(2.06) *\end{array}$ & $\begin{array}{l}0.17 \\
(2.03) *\end{array}$ & $\begin{array}{l}0.02 \\
(0.2)\end{array}$ & 0.13 & 0.00 \\
\hline 2008 & $\begin{array}{l}-0.39 \\
(>10) *\end{array}$ & $\begin{array}{l}0.55 \\
(7.8) *\end{array}$ & $\begin{array}{l}0.09 \\
(0.99)\end{array}$ & $\begin{array}{l}0.47 \\
(4.46) *\end{array}$ & $\begin{array}{l}-0.03 \\
(0.46)\end{array}$ & $\begin{array}{l}-0.09 \\
(1.74)\end{array}$ & 0.11 & 0.00 \\
\hline
\end{tabular}


Accounting and Management Information Systems

\begin{tabular}{|c|c|c|c|c|c|c|c|c|}
\hline Year & Intercept & $\mathrm{x}_{\mathrm{t}}$ & $\Delta \mathrm{x}_{\mathrm{t}}$ & $d_{t-1}$ & $\Delta c_{t}$ & $\Delta \mathrm{oa}_{\mathrm{t}-1}$ & Adj. $R^{2}$ & Model $\mathrm{p}$ \\
\hline 2009 & $\begin{array}{l}0.51 \\
(>10) *\end{array}$ & $\begin{array}{l}0.01 \\
(0.04)\end{array}$ & $\begin{array}{l}0.61 \\
(5.55) *\end{array}$ & $\begin{array}{l}-0.01 \\
(0.09)\end{array}$ & $\begin{array}{l}-0.06 \\
(0.49)\end{array}$ & $\begin{array}{l}0.10 \\
(1.24)\end{array}$ & 0.04 & 0.00 \\
\hline 2010 & $\begin{array}{l}0.29 \\
(>10) *\end{array}$ & $\begin{array}{l}0.53 \\
(3.39) *\end{array}$ & $\begin{array}{l}0.39 \\
(2.76) *\end{array}$ & $\begin{array}{l}-0.18 \\
(0.78)\end{array}$ & $\begin{array}{l}0.15 \\
(1.49)\end{array}$ & $\begin{array}{l}0.06 \\
(0.68)\end{array}$ & 0.05 & 0.00 \\
\hline 2011 & $\begin{array}{l}-0.09 \\
(9,42) *\end{array}$ & $\begin{array}{l}0.62 \\
(5.70) *\end{array}$ & $\begin{array}{l}0.49 \\
(3.98) *\end{array}$ & $\begin{array}{l}0.28 \\
(1.74)\end{array}$ & $\begin{array}{l}0.08 \\
(1.38)\end{array}$ & $\begin{array}{l}-0.12 \\
(2.12) *\end{array}$ & 0.1 & 0.00 \\
\hline 2012 & $\begin{array}{l}0.12 \\
(>10) *\end{array}$ & $\begin{array}{l}0.45 \\
(5.02) *\end{array}$ & $\begin{array}{l}0.54 \\
(4.85) *\end{array}$ & $\begin{array}{l}0.28 \\
(1.83)\end{array}$ & $\begin{array}{l}0.05 \\
(1.55)\end{array}$ & $\begin{array}{l}0.00 \\
(0.02)\end{array}$ & 0.11 & 0.00 \\
\hline 2013 & $\begin{array}{l}0.35 \\
(>10) *\end{array}$ & $\begin{array}{l}0.33 \\
(2.29) *\end{array}$ & $\begin{array}{l}0.81 \\
(5.08) *\end{array}$ & $\begin{array}{l}0.50 \\
(2.57) *\end{array}$ & $\begin{array}{l}0.15 \\
(2.24) *\end{array}$ & $\begin{array}{l}0.17 \\
(1.82)\end{array}$ & 0.08 & 0.00 \\
\hline 2014 & $\begin{array}{l}0.02 \\
(1.6)\end{array}$ & $\begin{array}{l}0.54 \\
(3.98) *\end{array}$ & $\begin{array}{l}0.56 \\
(3.13) *\end{array}$ & $\begin{array}{l}0.45 \\
(2.26) *\end{array}$ & $\begin{array}{l}0.31 \\
(2.11) *\end{array}$ & $\begin{array}{l}0.24 \\
(2.14) *\end{array}$ & 0.11 & 0.00 \\
\hline 2015 & $\begin{array}{l}-0.06 \\
(6.45) *\end{array}$ & $\begin{array}{l}0.48 \\
(5.05) *\end{array}$ & $\begin{array}{l}0.41 \\
(4.36) *\end{array}$ & $\begin{array}{l}0.14 \\
(1.03)\end{array}$ & $\begin{array}{l}0.17 \\
(2.54) *\end{array}$ & $\begin{array}{l}0.08 \\
(1.51)\end{array}$ & 0.10 & 0.00 \\
\hline
\end{tabular}

Note: As defined in Section 3.1, the independent variables include the comprehensive income $\left(\mathrm{x}_{\mathrm{t}}\right)$, lagged dividends $\left(\mathrm{d}_{\mathrm{t}-1}\right)$, change in cash investments $\left(\Delta \mathrm{c}_{\mathrm{t}}\right)$ and lagged change in operating assets $\left(\Delta \mathrm{oa}_{\mathrm{t}-1}\right)$. The independent variables have been deflated by the lagged market equity $\mathrm{p}_{\mathrm{t}-1}$. Inside the parentheses, the absolute value of the regression weight divided by the heteroscedasticity robust standard error is displayed. The corresponding p-values may be computed from the cumulative distribution function of the normal distribution; a value over 1.96 implies statistical significance on the 0.05 confidence level. The statistically significant coefficients (on the 0.05 confidence level) are marked by *.

Table 6 reports the effect of omitting the variables of comprehensive income and change in comprehensive income, lagged dividends, change in cash investments and change in lagged operating assets from the previous regression equation. The sample data set is divided into good news and bad news firms. Table 6 reports the regression coefficients averaged over the years under analysis. In this case, consider a regression weight averaged over the years; denote by $v^{2} r_{y}$ the estimated variance of the weight for year $y$. Then, the standard error of the averaged weight can be estimated by the following formula:

$$
\frac{1}{16} \sqrt{\sum_{y=2000}^{2015} v^{2} r_{y}}
$$

If independence of the regressions between the different years is assumed, then the average weight is approximately normally distributed with the estimated variance. While the independence assumption is difficult to verify empirically, the estimates do give a strong indication about the statistical significance of the sample under analysis. 
In Table 6, Model M1 shows the averaged coefficient estimate on the earnings level in the regression of returns on deflated earnings. Model M2 shows the estimate of the coefficient on earnings changes in the regression of returns on deflated earnings changes. Model M3 shows the averaged estimates from regressions of annual stock returns on both earnings and earnings changes. Model M4 shows the estimate of regression when the variable lagged dividend is added to earnings and earnings changes regression model. Model M5 shows the estimate of regression when the variable change in cash investments and the variable change in lagged operating assets are added to model M4.

Table 6. Regression of returns on earnings and earning changes: mean weights over the years with the absolute value of the average divided by the estimated standard error inside parentheses

\begin{tabular}{|c|c|c|c|c|c|c|c|}
\hline & Intercept & $\mathrm{x}_{\mathrm{t}}$ & $\Delta \mathrm{x}_{\mathrm{t}}$ & $\mathrm{d}_{\mathrm{t}-1}$ & $\Delta c_{t}$ & $\Delta \mathrm{oa}_{\mathrm{t}-1}$ & Adj. $R^{2}$ \\
\hline \multicolumn{8}{|c|}{ All firms } \\
\hline$\overline{\text { M1 }}$ & $\begin{array}{l}0.12 \\
(>10) *\end{array}$ & $\begin{array}{l}0.80 \\
(>10) *\end{array}$ & & & & & 0.07 \\
\hline M2 & $\begin{array}{l}0.12 \\
(>10) *\end{array}$ & & $\begin{array}{l}0.75 \\
(>10) *\end{array}$ & & & & 0.06 \\
\hline M3 & $\begin{array}{l}0.12 \\
(>10) *\end{array}$ & $\begin{array}{l}0.63 \\
(>10) *\end{array}$ & $\begin{array}{l}0.50 \\
(>10) *\end{array}$ & & & & 0.10 \\
\hline M4 & $\begin{array}{l}0.12 \\
(>10) *\end{array}$ & $\begin{array}{l}0.62 \\
(>10) *\end{array}$ & $\begin{array}{l}0.51 \\
(>10) *\end{array}$ & $\begin{array}{l}0.11 \\
(2.71) *\end{array}$ & & & 0.10 \\
\hline M5 & $\begin{array}{l}0.11 \\
(>10) *\end{array}$ & $\begin{array}{l}0.60 \\
(>10) *\end{array}$ & $\begin{array}{l}0.53 \\
(>10) *\end{array}$ & $\begin{array}{l}0.12 \\
(2.89) *\end{array}$ & $\begin{array}{l}0.14 \\
(6.3) *\end{array}$ & $0.01(0.5)$ & 0.10 \\
\hline \multicolumn{8}{|c|}{ Bad news firms } \\
\hline M1 & $\begin{array}{l}-0.26 \\
(>10) *\end{array}$ & $\begin{array}{l}0.40 \\
(>10) *\end{array}$ & & & & & 0.11 \\
\hline M2 & $\begin{array}{l}-0.27 \\
(>10) *\end{array}$ & & $\begin{array}{l}0.18 \\
(>10) *\end{array}$ & & & & 0.02 \\
\hline M3 & $\begin{array}{l}-0.26 \\
(>10) *\end{array}$ & $\begin{array}{l}0.40 \\
(>10) *\end{array}$ & $\begin{array}{l}0.01 \\
(0.66)\end{array}$ & & & & 0.11 \\
\hline M4 & $\begin{array}{l}-0.26 \\
(>10) *\end{array}$ & $\begin{array}{l}0.37 \\
(>10) *\end{array}$ & $\begin{array}{l}0.03 \\
(1.78)\end{array}$ & $\begin{array}{l}0.26 \\
(8.92) *\end{array}$ & & & 0.12 \\
\hline M5 & $\begin{array}{l}-0.26 \\
(>10) *\end{array}$ & $\begin{array}{l}0.39 \\
(>10) *\end{array}$ & $\begin{array}{l}0.01 \\
(0.41)\end{array}$ & $\begin{array}{l}0.25 \\
(8.47) *\end{array}$ & $\begin{array}{l}0.00 \\
(0.03)\end{array}$ & $\begin{array}{l}-0.03 \\
(2.53) *\end{array}$ & 0.13 \\
\hline \multicolumn{8}{|c|}{ Good news firms } \\
\hline M1 & $\begin{array}{l}0.42 \\
(>10) *\end{array}$ & $\begin{array}{l}0.14 \\
(2.75) *\end{array}$ & & & & & 0.00 \\
\hline M2 & $\begin{array}{l}0.41 \\
(>10) *\end{array}$ & & $\begin{array}{l}0.57 \\
(>10) *\end{array}$ & & & & 0.04 \\
\hline M3 & $\begin{array}{l}0.41 \\
(>10) *\end{array}$ & $\begin{array}{l}-0.02 \\
(0.41)\end{array}$ & $\begin{array}{l}0.58 \\
(>10) *\end{array}$ & & & & 0.04 \\
\hline
\end{tabular}


Accounting and Management Information Systems

\begin{tabular}{llllllll}
\hline & Intercept & $\mathrm{x}_{\mathrm{t}}$ & $\Delta \mathrm{x}_{\mathrm{t}}$ & $\mathrm{d}_{\mathrm{t}-1}$ & $\Delta \mathrm{c}_{\mathrm{t}}$ & $\Delta \mathrm{oa}_{\mathrm{t}-1}$ & Adj. $\mathrm{R}^{2}$ \\
\hline M4 & 0.42 & 0.02 & 0.56 & -0.37 & & & 0.04 \\
& $(>10) *$ & $(0.39)$ & $(>10) *$ & $(6.85) *$ & & & \\
M5 & 0.41 & -0.05 & 0.66 & -0.33 & 0.16 & 0.11 & 0.05 \\
& $(>10) *$ & $(1.00)$ & $(>10) *$ & $(6.33) *$ & $(3.87) *$ & $(2.89) *$ &
\end{tabular}

Note: As defined in Section 3.1, the independent variables include the comprehensive income $\left(\mathrm{x}_{\mathrm{t}}\right)$, lagged dividends $\left(\mathrm{d}_{\mathrm{t}-1}\right)$, change in cash investments $\left(\Delta \mathrm{c}_{\mathrm{t}}\right)$ and lagged change in operating assets $\left(\Delta \mathrm{oa}_{\mathrm{t}-1}\right)$. The independent variables have been deflated by the market equity, $\mathrm{p}_{\mathrm{t}-1}$. The corresponding p-values may be computed from the cumulative distribution function of the normal distribution; a standard error over 1.96 implies statistical significance on the 0.05 confidence level. The statistically significant coefficients (on the 0.05 confidence level) are marked by *.

The purpose of Table 6 is to examine the effect of omitting the key variables including the change in cash investments and the change in lagged operating assets from the regression equation (3). From Table 6, it is seen that the averaged coefficients on comprehensive income and the change of comprehensive income are statistically significant when all the observations are analyzed together, whereas partitioning occasionally leads to non-significant estimates. From Table 6 , the average coefficient on the earnings level in the regression of annual returns on deflated earnings levels from model M1 is significantly positive at the 0.01 level. The coefficient estimates on earnings changes in the regression of returns on deflated earnings changes in model M2 is also significantly positive at the 0.01 level. In model M3, the coefficient estimate on the earnings level is $0.40 \mathrm{for}$ bad news firms and on the earnings changes 0.58 for good news firms. In model M4, the variables lagged dividends, earnings levels and earnings changes as explanatory variables for returns are proven to be statistically significant at the 0.01 level when considering the whole data set. Between models M3 and M4, the coefficient on earnings levels decreases from 0.63 to 0.62 when all observations are analyzed together, while in the case of the bad news firms the coefficient estimate on earnings changes decreases from 0.40 to 0.37 . The results in Table 6 imply that the first type of accounting conservatism, which is associated with investments in positive net present value projects as reflected by a positive coefficient on change in cash investments, may be empirically supported when the results are analyzed based on different firm characteristics.

\subsubsection{Test of hypothesis 2}

When it comes to the second type of accounting conservatism, which is theoretically captured by a positive coefficient on the change in lagged operating assets, based on the results in Table 5 and Table 6, there is no clear evidence to establish the association with the application of accounting rules to operating assets in place. In Table 6, the model M5 shows the estimate of regression when the variable change in cash investments and the variable change in lagged operating assets are further added to model M4. As the mean of the estimates of 
the coefficient on change in lagged operating assets is not statistically significant when all observations are analyzed together, and thus there is no strong empirical evidence to support the second type of accounting conservatism associated with the over-depreciation of assets in place. This implies that a positive change in lagged operating assets does not pervasively reflect the second type of accounting conservatism, which is associated with the application of accounting rules to operating assets in place.

\section{Discussion and conclusions}

\subsection{Conclusions}

Financial reporting is increasingly dependent on an in-depth understanding of the imperfections in the capital markets as well as the impact of the accounting standards on firm performance. The effect of accounting regulations on the firms' reporting practices can be evaluated via a firm's change in cash investments and its operating assets. This study examines the change in cash investments and the change in lagged operating assets as two measures of accounting conservatism using regression of returns on earnings based on the previous literature (Easton \& Pae, 2004). In doing so, this study employs a robust set of data with different market to book ratios and corporate governance characteristics collected from Compustat North America Fundamentals Annual firm year observations for the time period of January 1998 to December 2015 fiscal years to better understand how accounting conservatism affects the relations between stock returns and accounting variables, which is also the research question of this paper. The value relevance of accounting in a longitudinal study is also examined with the regression of returns on earnings by incorporating the GAAP conservative accounting principles in the earnings-return regression estimation. Compared to the previous studies, any potential improvement in the research method is provided using a regression weight averaged over the years. Prior to performing an OLS regression analysis of the data, an additional power test for heteroscedasticity is performed to ensure consistent results. The findings of the study indicate that there is some empirical evidence to accounting conservatism reflecting the effects of investments in positive net present value projects until later periods when accounting conservatism is measured using the change in cash investments. However, when it comes to the variable lagged operating assets, the estimates of the coefficient on operating assets are not found to be statistically significant.

\subsection{Limitations of the study and future research}

According to Lipe et al. (1998), contemporaneous relation between stock returns and accounting earnings is nonlinear, different for profits and losses and different 
across firms. Empirical results have confirmed that earnings/return relation varies with different firm characteristics (Isshaq \& Faff, 2016). One of the solutions proposed to the omitted variable problem is to add more control variables. However, this type of solution suffers from several drawbacks. In this case, the variables change in cash investments and lagged operating assets might not be accurate proxies to measure the omitted determinants of accounting conservatism. In addition, inference problems are also likely to occur when analyzing multiple motivations using proxies having a varying degree of measurement errors especially when the underlying effects are correlated.

It is acknowledged that the analysis of the accounting rules and their changes over the time on the behavior of firms restricts the very nature of accounting conservatism. In addition, a wide stream of research confirms the importance of reporting incentives for high quality financial reporting (Gaynor et al., 2016). These incentives crucially depend on the personality of the top management and the effectiveness of monitoring by the firm owners. Therefore, one of the solutions to improve the current research of accounting conservatism and financial reporting is to include variables controlling for the change in the top management. Other important variables to consider in the future research include the change in compensation schemes, the redesign of the board of directors, new corporate governance procedures and significant changes in the measurement rules. Given that accounting conservatism is closely linked with corporate governance, the regression of returns on earnings levels and earning changes should take into account the effect of corporate governance and aim to empirically test the results either in a similar or a different research framework to further our understanding in corporate financial reporting in an international context.

\subsection{Discussions}

In this paper, the change in cash investments and the change in lagged operating assets are empirically evaluated as the measures of the two types of accounting conservatism in the regression of returns on earnings. It is concluded that accounting does not record the payoffs from positive new present value projects until the associated future sales have been recorded. This is empirically shown by the fact that the payoffs from the positive net present value projects are not captivated in book value and earnings, as reflected by the change in cash investments in the returns-earnings regression model. However, when it comes to the accounting rules and procedures, this does not seem to lead to an understatement of book value and accounting earnings in the prior, current and future periods, as reflected by the estimation results of the lagged operating assets in the returns-earnings regression model.

The results suggest that there exist differences in accounting conservatism between good news firms and bad news firms. Firms with net good news tend to invest more 
in positive net present value projects whereas, for firms with negative returns, accounting seems to have recorded a lower level of decline in value than what the market has recorded. Given that there exists no difference in accounting conservatism associated with the application of accounting rules and procedures, such as the aggressive depreciation policy, on the financial performance of firms, the empirical evidence of incremental explanatory power in lagged operating assets, as the measure for the second type of accounting conservatism, cannot be generalized. Nevertheless, there is an improvement in the explanatory power of the estimates of the coefficients on earnings levels and earnings changes when the variables associated with accounting conservatism are incorporated in the analysis. The results confirm findings in prior studies, which together suggest that researchers should include change in cash investments in models that examine the value relevance of accounting information.

\section{References}

Ball, R. \& Shivakumar, L. (2008) "How much new information is there in earnings", Journal of Accounting Research, vol. 46: 975-1016

Ball, R. \& Shivakumar, L. (2005) "Earnings quality in UK private firms: comparative loss recognition", Journal of Accounting and Economics, vol. 39: $83-128$

Ball, R. \& Brown, P. (1968) "An empirical analysis of accounting income numbers", Journal of Accounting Research, vol. 6: 159-178

Ball, R., Kothari, S.P. \& Nikolaev, V. (2013) "On estimating conditional conservatism", The Accounting Review, vol. 88: 755-787

Basu, S. (1997) "The conservatism principle and the asymmetric timeliness of earnings", Journal of accounting and economics, vol. 24: 3-37

Callen, J. L., Segal, D. \& Hope, O. K. (2010) "The pricing of conservative accounting and the measurement of conservatism at the firm-year level", Review of Accounting Studies, vol. 15, no. 1:145-178

Callen, J. L., Chen, F., Dou, Y. \& Xin, B. (2016) "Accounting conservatism and performance covenants: a signaling approach", Contemporary Accounting Research, vol. 33, no. 3: 961-988

Easton, P. \& Pae, J. (2004) "Accounting conservatism and the relation between returns and accounting data", Review of Accounting Studies, vol. 9: 495-521

Easton, P. \& Harris. T. (1991) "Earnings as an explanatory variable for returns", Journal of Accounting Research, vol. 29: 19-36

Feltham, G. \& Ohlson, J. (1995) "Valuation and clean surplus accounting for operating and financial activities", Contemporary Accounting Research, vol. 11: $689-731$

Feltham, G. \& Ohlson, J. (1996) "Uncertainty resolution and the theory of depreciation measurement", Journal of Accounting Research, vol. 34: 209234

Vol. 18, No. 1 
Gaynor, L. M., Kelton, A. S., Mercer, M. \& Yohn, T. L. (2016) "Understanding the relation between financial reporting quality and audit quality", Auditing: A Journal of Practice \& Theory, vol. 35, no. 4: 1-22

Givoly, D., Hayn, C. \& Nataragan, A. (2007) "Measuring reporting conservatism", The Accounting Review, vol. 82: 65-107

Glover, J. \& Lin, H. H. (2018) "Accounting conservatism and incentives: Intertemporal considerations", The Accounting Review, vol. 91: 181-201

Goh, J., Lee, H.Y. \& Lee, J.W. (2013) "Majority shareholder ownership and real earnings management: evidence from Korea", Journal of International Financial Management \& Accounting, vol. 24: 26-61.

Isshaq, Z. \& Faff, R. (2016) "Stock liquidity risk and the cross-sectional earnings-returns relationship", Journal of Business Finance \& Accounting, vol. 43, no. 9-10:1121-1141

Khan, M. \& Watts, R. L. (2009) "Estimation and empirical properties of a firmyear measure of accounting conservatism", Journal of Accounting and Economics, vol. 48, no. 2-3: 132-150

Lara, J. M. G., Osma, B. G. \& Penalva, F. (2016) "Accounting conservatism and firm investment efficiency", Journal of Accounting and Economics, vol. 61, no. 1:221-238

Lipe, R., Bryant, L. \& Widener, S. (1998) "Do non-linearity, firm-specific coefficients, and losses represent distinct factors in the relation between stock returns and earnings", Journal of Accounting and Economics, vol. 25, no. 2: $195-214$

Mason, L. (2004) "The impact of accounting conservatism on the magnitude of the differential information content of cash flows and accruals", Journal of Accounting, Auditing \& Finance, vol. 19, no. 3: 249-282

Penman, S. \& Zhang, X. (2004) "Accounting conservatism, the quality of earnings, and stock returns", The Accounting Review, vol. 77: 237-264

Pope, P. F. \& Walker, M. (2003) "Ex-ante and ex-post accounting conservatism, asset recognition and asymmetric earnings timeliness", working paper, Lancaster University and The University of Manchester.

White, H. (1980) "A heteroskedasticity-consistent covariance matrix estimator and a direct test for heteroskedasticity", Econometrica, vol. 48, no. 4: 817-838.

Wu, J. S. \& Zhang, I. X. (2017) "Mandatory IFRS adoption and the role of accounting earnings in CEO turnover", Contemporary Accounting Research, in press 